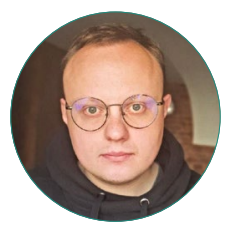

D. M. Zhikharevich

\title{
HOW ALGORITHMS BECAME CAPITALIST. \\ BOOK REVIEW OF: ZUBOFF SH. SURVEILLANCE CAPITALISM: THE FIGHT FOR A HUMAN FUTURE AT THE NEW FRONTIER OF POWER. NEW YORK: PUBLICAFFAIRS, 2019
}

\section{For citation:}

Zhikharevich D. M. (2021) How Algorithms Became Capitalist. Monitoring of Public Opinion: Economic and Social Changes. No. 1. P. 398-409. https://doi.org/10.14515/monitoring.2021.1.1907. Book Review of: Zuboff Sh. Surveillance Capitalism: The Fight for a Human Future at the New Frontier of Power. New York: PublicAffairs, 2019.

\section{Правильная ссылка на статью:}

Жихаревич Д. М. Как алгоритмы стали капиталистическими // Мониторинг общественного мнения: экономические и социальные перемены. 2021. № 1. С. 398-409. https:// doi.org/10.14515/monitoring.2021.1.1907. Рец. на кн.: Zuboff Sh. Surveillance Capitalism: The Fight for a Human Future at the New Frontier of Power. New York: PublicAffairs, 2019. (In Eng.) 
HOW ALGORITHMS BECAME CAPITALIST. BOOK REVIEW OF: ZUBOFF SH. SURVEILLANCE CAPITALISM: THE FIGHT FOR A HUMAN FUTURE AT THE NEW FRONTIER OF POWER. NEW YORK: PUBLICAFFAIRS, 2019

Dmitrii M. ZHIKHAREVICH ${ }^{1,2}-$ Research Fellow, Science and Technology Studies Centre (STS Centre); Researcher, International Research Laboratory TANDEM E-MAIL:dzhikharevich@eu.spb.ru https://orcid.org/0000-0002-2518-7858

\footnotetext{
${ }^{1}$ European University at Saint Petersburg, Saint Petersburg, Russia

2 Saint Petersburg State University, Saint Petersburg, Russia
}

Acknowledgments. The study was supported by Russian Science Foundation: Grant No. 18-78-10049.
КАК АЛГОРИТМЫ СТАЛИ КАПИТАЛИСТИЧЕСКИМИ. РЕЦ. НА КН.: ZUBOFF SH. SURVEILLANCE CAPITALISM: THE FIGHT FOR A HUMAN FUTURE AT THE NEW FRONTIER OF POWER. NEW YORK: PUBLICAFFAIRS, 2019

ЖИХАРЕВИЧ Дмитрий Михайлович научный сотрудник, центр исследований науки и технологий (центр STS), Европейский университет в СанктПетербурге, Санкт-Петербург, Россия; исследователь, международная исследовательская лаборатория ТАНДЕМ, Санкт-Петербургский госудраственный университет, Санкт-Петербург, Россия E-MAIL:dzhikharevich@eu.spb.ru https://orcid.org/0000-0002-2518-7858

Благодарность. Работа выполнена при поддержке Российского научного фонда: грант № 18-78-10049.

This book is monumental, and claiming that a short review can do it justice would be laughable. Hence, like an Annual Review author, I must cheat either breadth or depth [Abbott, 1993: 187], and I choose the former. Let me spare the reader the tedious part: I will not retell Surveillance Capitalism content chapter by chapter. Instead, I will focus on what I think is its most original aspect, namely, the theory of surveillance capitalism outlined in the first part of Zuboff's edifice.

So, what is surveillance capitalism? Zuboff starts with a dictionary-like definition which serves as an epigraph and lists as many as eight (!) related meanings, including 'a new economic order', 'a parasitic economic logic', 'a rogue mutation of capitalism', 'the foundational framework of a surveillance economy', and 'the origin of a new instrumentarian power', among other things [Zuboff, 2019]. Some of these initial formulations are further refined throughout the book's eighteen chapters. Yet, since all meaning is relational, such dictionary-like definitions are of little use unless adequately contextualised within the author's network of concepts. One of the definitions Zuboff provides halfway through the second chapter is a good place to start: surveillance capitalism is a 'new market form' and a 'unique logic of accumulation in which surveillance is a foundational mechanism in the transformation of investment into profit' [Zuboff, 2019: 55]. Note that surveillance does not enter the equation as merely a 'moment' of capital accumulation, as Marxists would (perhaps) have it; it is much more than an external appendage to the circuit of capital. Instead, it is the very foundation on which capital accumulation, that is, the transformation of investment 
into profit, rests. As such, it is new and even unprecedented: according to Zuboff, surveillance capitalism 'is a new actor in history, both original and sui generis' [ibid.: 20]. The book documents its emergence within (Part 1), and diffusion beyond (Part 2), the 'networked sphere', as well as analyses the new form of 'instrumentarian' power it gave rise to (Part 3).

\section{What is Surveillance Capitalism?}

To be sure, the concept of 'surveillance capitalism' is not of Zuboff's coinage. Marxist political economists John Bellamy Foster and Robert McChesney used the term to describe, focusing on the U.S. case, the most recent amalgamation of monopoly-finance capital, the national security state, and digital technology on the pages of Monthly Review [Foster, McChesney, 2014]. Zuboff does address some of these issues, too, but from a different vantage point. Firstly, her preferred unit of analysis is a firm, like Apple or Google, considered simultaneously as the point of origin and the embodiment of new capitalism's economic imperatives. As different from the holistic perspective of political economists, Zuboff locates the essential dynamics at the firm level, where new logics of capital accumulation originate and from where they diffuse. Hardly any reviewer failed to quote at least one of these suggestive lines: 'Google is to surveillance capitalism what the Ford Motor Company and General Motors were to mass-production-based managerial capitalism' [Zuboff, 2019: 65]; 'Google invented and perfected surveillance capitalism in much the same way that a century ago General Motors invented and perfected managerial capitalism' [ibid.: 16]. In Zuboff's view, Google became 'the pioneer, discoverer, elaborator, experimenter, lead practitioner, role model and a diffusion hub' [ibid.: 65] of the new model of capitalism, later adopted by Facebook, Microsoft, and other firms, including those operating beyond the Internet sector.

Secondly, Zuboff's understanding of surveillance is much more specific and less literal than the one suggested by Foster and McChesney. For Zuboff, surveillance has less to do with CCTV ${ }^{1}$ cameras on the high street feeding into a government-run (and occasionally leaking) face recognition system than with the cookie files stored in your browser. In her very first academic paper on surveillance capitalism, Zuboff makes clear that by 'surveillance' she means something like 'predict[ing] and modify[ing] human behaviour as a means to produce revenue and market control' [Zuboff, 2015: 75]. This network of concepts unfolds in the book, making their meaning visible: surveillance capitalism is a form of capitalism whose basic operation is the rendition of human experience into behavioural data to manufacture prediction products and sell them on behavioural futures markets. To be sure, companies do capture user data all the time, but, according to Zuboff, this does not amount to surveillance capitalism as long as behavioural value, that is, the insights into user behaviour derived from user data analytics, is reinvested to improve user experience. Zuboff calls this process 'behavioural value reinvestment cycle', whereby 'only behavioural data needed for service improvements are rendered' [Zuboff, 2019: 72]. Capitalism begins with a shift from the behavioural value reinvestment cycle to the hunt for behavioural surplus: 'More behavioural data are rendered than required for service improvements. This

\footnotetext{
${ }^{1}$ Closed Circuit Television.
} 
surplus feeds machine intelligence - the new means of production - that fabricates predictions of user behaviour. These products are sold to business customers in new behavioural futures markets' [ibid.: 97]. Make no mistake, surveillance capitalists do not care about your UX², even though they usually say otherwise. Instead, it is the "data exhaust' what they are after: additional data points, unnecessary from the point of view of UX improvement, but extremely valuable for predicting users' future behaviour. Zuboff calls these data points 'behavioural by-products' or 'collateral data', such as 'the number and pattern of search terms, how a query is phrased, spelling, punctuation, dwell times, click patterns, and location' [ibid.: 69]. Capturing, or, in Zuboff's preferred phrasing, 'extracting' this behavioural surplus, is key to making profits on behavioural futures markets, since it enhances the value of surveillance capitalists' prediction products.

Now, this is starting to look familiar. From Marx's general formula of capital Polanyi's embedded markets, we know that production for subsistence plus selling occasional surpluses is quite different from production for the purposes of selling. The discipline of market competition introduces new forms of dependency, or, in Zuboff's terms, new 'economic imperatives', and this changes everything. In the words of the great Marxist historian Ellen Meiksins Wood, the rise of capitalism, or the ultimate 'market society', precisely means this shift 'from opportunity to imperative', whereby market exchange ceases to be a voluntary option and becomes the only way to subsist [Wood, 1994]. Hence, if one drops the assumptions of liberal anthropology, suggesting that markets basically are spontaneous emanations of human nature and will appear anywhere unless blocked by some artificial constraints, it becomes necessary to explain the emergence of the market imperative, rather than merely positing it. Zuboff is up for the task, approaching it with a narrative of Google's discovery of behavioural surplus that prompted a shift from behavioural value reinvestment cycle to behavioural surplus extraction.

Larry Page and Sergey Brin invented the web search algorithm PageRank in 1996, but, despite the brilliance of technology, they struggled to find a way to sustainable revenues. Indeed, Google's early business model was based on providing web services to portals like Yahoo! through licensing, as well as sponsored ads linked to search keywords. Zuboff carefully documents the early years of the fledgling company, noting the founders' disgust towards advertising and their venture capitalist backers' confidence in the company's ability to find some way of monetising the algorithm. But then came the dot-com bubble, and Google's investors suddenly became seriously interested in returns on their money. Analysts sometimes call venture capital 'patient capital', but, as Zuboff shows, this was not the case at Google: scared of the bubble and its consequences, venture capitalists became impatient and declared a state of emergency. It is in this context that Google learned to valorise 'data exhaust' that used to be 'haphazardly stored and operationally ignored' [Zuboff, 2019: 69]. In Zuboff's telling, the company's transition from occasional advertising deals and licenses to surveillance revenues was accomplished when Amit Patel, the data scientist credited with 'the groundbreaking insight into the significance of Google's accidental data caches', met Eric Schmidt, the new CEO hired in 2002. Schmidt turned Patel's insight into a strategy,

\footnotetext{
2 User Experience.
} 
shaping Google's 'specific response to financial emergency', and opening up the way for the 'crucial mutation that ultimately turned... the Internet, and the very nature of information capitalism toward an astonishingly lucrative surveillance project' [ibid.: 77].

\section{What is Wrong with Surveillance Capitalism?}

Google's realisation that data exhaust is an untapped source of value is the turning point not only for surveillance capitalism but also for Zuboff's narrative. Suddenly a business school professor talking about selected cases from recent corporate history becomes a social theorist well-versed in the critical sociology playbook. Zuboff shows how competitive pressures push surveillance capitalism beyond the Internet and into the real world, as Google, Facebook, and their likes aggressively acquire startups developing technologies for the Internet of things, thus setting in motion the digitisation of the physical. On the other hand, some businesses that are not digitally native, like Verizon and other telecom companies, are quickly picking up some of the profit-making techniques of the pristine surveillance capitalists. As a result, surveillance is increasingly becoming omnipresent with every new 'smart' device - a phone, a watch, or a home - entering our everyday lives. For Zuboff, this means that surveillance capitalists are now also able to modify human behaviour by prompting, or rather nudging users to engage with their services more intensively, thus producing more data points to be fed into predictive analytics and adding even more value to the prediction products manufactured by the owners of the means of behaviour modification. This point allows Zuboff to argue that human experience itself now joins the Polanyian triumvirate of 'fictitious commodities', becoming 'subjugated to surveillance capitalism's market mechanisms and reborn as “behaviour"' [Zuboff, 2019: 100]. Behaviour is then turned into data from which predictions are fabricated to be exchanged in the new behavioural futures markets.

In this story, Google and Facebook feature as the agents of surveillance capitalism's primitive accumulation, claiming human experience as a free good to be commodified, thus threatening to inflict as much damage to human nature as industrial capitalism did to nature tout court. Zuboff goes on, arguing, with Arendt [2004], that primitive accumulation, in fact, never stops, thus becoming accumulation by 'digital dispossession' [Zuboff, 2019: 98-100]. Here Zuboff draws on David Harvey's [2003] famous concept, arguing that 'surveillance assets', the by-products of users' search actions, are claimed at no cost. Surveillance capitalists rely on the classic set of capitalist tactics to create the 'first-mover advantage' for themselves. They strive to occupy unregulated territories of the digital world as fast as possible, set a precedent, and then push the regulators back with the help of the network effects, expensive lawyers, and revolving doors between private companies and the policy circles. And yet, it is not capitalism per se that worries Zuboff the most. She dismisses the standard liberal critiques of the 'platform economy' as monopolistic, playing the Arendtian tune and appealing to the unprecedented character of surveillance capitalism as a form of power, not just monopoly power: 'Even when surveillance capitalist operations are also monopolistic and a threat to privacy, the existing categories nevertheless fall short in identifying and contesting the most crucial and unprecedented facts of this new regime' [Zuboff, 2019: 20]. 
So, what is wrong with surveillance capitalism? Basically, it is surveillance. Firstly, Zuboff is worried about privacy, or, more precisely, about the rights to privacy. These rights enable one to choose whether to share something or keep it secret; deprived of privacy rights, one loses an important decision right as well. Surveillance capitalism triggers a massive redistribution of these rights, whereby individuals are increasingly deprived of their choices 'in the matter of what about their lives remains secret', and their privacy rights accrue to surveillance capitalists [Zuboff, 2015: 82-83]. Like other capitalists, the latter take what they need without asking by planting surveillance technologies into unregulated domains of everyday life and then mount sophisticated defenses of what has already been taken. Ironically, these defenses often involve appeals by surveillance capitalists to their rights to privacy, for example, in the form of legal protections derived from the trade secrets law.

Secondly, unequal distribution of the rights to privacy goes hand in hand with the increasingly unequal distribution of knowledge in society. The commodification of human experience by turning it into 'behaviour', as if taken from the pages of B. F. Skinner's writings [see, e.g., Skinner, 1976], operates through a form of indifference: the products of surveillance capitalism 'manage to be derived from our behaviour while remaining indifferent to our behaviour. Its products are about predicting us, without actually caring what we do or what is done to us' [Zuboff, 2019: 71]. This indifference brings Zuboff to her larger concern: the distortion of what she calls the 'social division of learning', a concept derived from Durkheim's Division of Labour. Here Zuboff draws on her own earlier studies of workplace automation. Back in the 1980s, she argued that, as different from industrial automation, the advent of 'computer-mediated work' did not simply replace human labour but added a new layer of complexity to the entirety of organisational life, rendering 'events, objects, processes, and people...visible, knowable, and shareable in a new way. The world is reborn as data and the electronic text is universal in scale and scope' [Zuboff, 2015: 77]. Information technology's capacity not only to automate but also to 'informate', therefore, is pregnant with an emancipatory possibility of making work 'smart' and turning learning into a new form of labour [Zuboff, 1988: 395; quoted in Zuboff, 2015: 76]. Yet whether this possibility will become a reality is contingent on the balance of power within and across organisations. Surveillance capitalism realises the bad scenario, the darkening of the digital dream, whereby the massive electronic text produced by computer-mediated social life is turned into an engine for private profits.

Consequently, the privatisation of the division of learning in society, 'the critical axis of social order in the $21^{\text {st }}$ century', changes the relationships between knowledge and power in dramatic ways. It is interesting to note that Foucault is barely mentioned on the pages of Zuboff's book, even though some formulations will ring the relevant bells with the readers who had been through a French theory class. For Zuboff, however, the division of learning in society seems to refer to an unlikely combination of Durkheim's 'division of labour in society' and Hayek's ‘use of knowledge in society'. Indeed, as surveillance capitalism increasingly becomes what Zuboff calls 'reality business', migrating from the Internet into the 'real' world, its economic imperatives become salient for the new hybrid of the digital and the physical created by the Internetof-Things (IoT), Augmented Reality (AR), and other similar technologies. Surveillance 
capitalists' ultimate commodity is the certainty of behavioural predictions, and as such, it works against human freedom premised upon the inherent indeterminacy of human action. Here Zuboff draws both on Hayek's ideas about the distributed character of social knowledge and Arendt's theory of human action as defined by its power to create new things. Surveillance capitalism's quest for certainty embodied in predictive algorithms and 'smart' contracts work to eliminate this basic human quality, thereby also threatening to erode the social itself because, in the world of total certainty, there is no place for trust-based relationships and even for most of the legal institutions, starting from the simple contract. By gaining control over the division of learning in society, surveillance capitalists become not only rich but also immensely powerful while remaining completely unaccountable. Zuboff calls their power 'instrumentarian' and reserves the nickname 'Big Other' for the infrastructure of computer mediation that underpins it. By taking our data from us, surveillance capitalists also take our right to a sanctuary: there is no place to hide from the Big Other's decentralised surveillance. As different from much of contemporary writing in the subfield of 'surveillance studies', it is not Foucault or Deleuze (with their respective notions of disciplinary vs. control society), but Orwell and Arendt that Zuboff talks to.

\section{What is Wrong with Zuboff's Surveillance Capitalism?}

So far, so good - or, rather, so bad. From the normative point of view, Zuboff's critique calls for the new modes of collective action capable of resisting surveillance capitalism, a Polanyian double movement for the digital age [see Polanyi, 1957]. Surveillance capitalism is undesirable, but there is nothing inevitable about it. Zuboff insists that the quest for 'behavioural surplus appropriation' does not result from some technological necessity driving the development of Big Data; instead, this turn of events results from historical contingency. Surveillance capitalism 'was invented by a specific group of human beings in a specific time and place' [Zuboff, 2019: 85], namely, at Google in the aftermath of the dot-com bubble. However, this invention was made possible by some larger-scale social and economic forces: not just the dot-com crisis per se, but also the spread of neoliberalism and financialisation of the corporate world. Combined, the latter two trends stabilised the idea that the only thing business corporations should care about is shareholder value maximisation, thus setting the stage for surveillance capitalism's distinctly dismissive attitude to accountability and responsibility to anybody but its investors. Therefore, surveillance capitalism is a product of specific historical circumstances that could have been different; it is undesirable but mutable. To drive the point home and accomplish the critical gesture, Zuboff also needs to show the direction of change, a normative project. It is here where she betrays some of the problematic assumptions of her theory.

It turns out that the crucial problem with surveillance capitalism is the lack of fundamental 'reciprocities' between capitalists and their 'populations'. What makes surveillance capitalism a particularly 'rogue' mutation of capitalism is that its users and customers do not overlap. Users who like Facebook pages and search the web with Google do improve the algorithms by allowing the companies to capture their data, but at the end of the day it is the advertisers who buy the 'prediction products' manufactured from these data. In Zuboff's [2019: 17] words, 
Surveillance capitalism's products and services are not the objects of a value exchange. They do not establish constructive producer-consumer reciprocities. Instead, they are the 'hooks' that lure users into their extractive operations in which our personal experiences are scraped and packaged as the means to others' ends. We are not surveillance capitalism's 'customers'. Although the saying tells us 'If it's free, then you are the product', that is also incorrect. We are the sources of surveillance capitalism's crucial surplus: the objects of a technologically advanced and increasingly inescapable raw-material-extraction operation. Surveillance capitalism's actual customers are the enterprises that trade in its markets for future behaviour.

Indeed, being a customer and a source of the raw materials supply is not the same. In the former case, what Zuboff calls 'producer-consumer reciprocity' obtains, and the consumers have the levers to hold the firm accountable by exercising one of Albert O. Hirschman's [1970] three options of exit, voice, and loyalty. Conversely, no such reciprocity is possible between the firm and its raw materials; this relationship is not one of 'value exchange', but of extraction pure and simple. Thus, surveillance capitalism deviates from the historical relationship between markets and democracy, threatening to become the digital version of 'a pre-modern absolutist authority' that evades public scrutiny or 'the traditional market pressures of consumer reciprocity and choice' [Zuboff, 2015: 83]. UX improvements are just a way of 'cornering' new sources of raw materials supply, not the means of beating the competition. Instead, surveillance capitalist competition is about better prediction products and advertising revenues flowing from their sales.

But wait, something does not add up here. Should not surveillance capitalists' structural independence from their users work both ways? In other words, what locks the users in the surveillance economy in the first place? If there is no market exchange between surveillance capitalist companies and their users, to paraphrase Wood [1994], there is neither 'opportunity', nor 'imperative'. Since the users' subsistence does not depend on the surveillance economy (defined, somewhat tautologically, as 'a surveillance-based economic order'), what is so tragic about it that Zuboff even feels compelled to invoke the Faustian compact? The answer lies in Zuboff's theoretical assumptions rooted not in critical sociology but, somewhat surprisingly, in modernisation theory. Following Durkheim's argument that modern division of labour does not only unlock productivity but creates new 'conditions of existence', triggering the shift from mechanic to organic solidarity, Zuboff suggests that it is the new 'conditions of existence that create and sustain demand for surveillance capitalism's services' [Zuboff, 2019: 100]. To theorise these conditions, she draws on the theory of reflexive modernisation outlined by Ulrich Beck, Scott Lash, Anthony Giddens, and Ronald Inglehart, explicitly invoking one of its central concepts, the 'second modernity' [see, e. g., Beck, Bonss, Lau, 2003]. For Zuboff, the most important aspect of modernisation is progressive individualisation, whereby the individual becomes the locus of moral agency and choice' [Zuboff, 2019: 37]. Having emerged from the mass-production world of the first modernity, individuals now require individualised consumption, unmediated by standardised distribution channels. Ultimately, the driving force of all individual activity, consumption included, is the need to live an 'effective life' under the 
given conditions of existence that evolve in modernisation. Very much in tune with the turn-of-the-century mood of reflexive modernisation theory, Zuboff sees consumption as a part of individual lifestyle projects, thus adding an existential dimension to it. Historically changing conditions of existence connect supply and demand and trigger the emergence of new market forms, which Zuboff equates with forms of capitalism. New market forms emerge in specific historical and existential circumstances; some of them die out, while others manage to catch on, get adopted, and eventually institutionalised in the producer-consumer reciprocities that are tragically lacking in surveillance capitalism [Zuboff, 2015: 77].

Put simply, surveillance capitalism is a 'bad' way of responding to the new conditions of existence that individuals face on the verge of the third modernity. In his insightful review of Zuboff's book, Evgeny Morozov [2019] notes that her theory is a strange hybrid of functionalist business history à la Alfred Chandler and somewhat naïve appreciation of the wonders of the digital age characteristic of Italian post-workerist thought, making it a Harvard Business School version of Toni Negri. This description is accurate, as evidenced by the way Zuboff discusses capitalism. Recall that, in her view, surveillance capitalism is a 'rogue mutation' of capitalism, implying that there is also a proper, or, as she prefers to call it, 'rational' capitalism. Already in the Introduction, Zuboff insists that it is necessary to distinguish between capitalism and surveillance capitalism: 'When a firm collects behavioural data with permission and solely as a means to product or service improvement, it is committing capitalism but not surveillance capitalism' [Zuboff, 2019: 28]. Moreover, collecting data to customise service is precisely what firms operating in the new, third-modernity information capitalism are supposed to do. While Google is the ultimate embodiment of surveillance capital, for Zuboff, the opposite model is best exemplified by...Apple, and, more specifically, by iPod, which, together with the iTunes platform, 'made it possible for listeners to continuously reconfigure their songs at will' [ibid.: 34]. It turns out that the distance between the good, 'rational' information capitalism and the 'rogue' surveillance capitalism is not that great after all. Through different analytical lenses, the two corporations would, perhaps, be characterised as belonging to a common category of 'platforms' [see Srnicek, 2016]. Perhaps behavioural surplus extraction is not that different from behavioural reinvestment cycle to amount to an entirely new economic imperative, rather than a strategy of a few powerful corporations?

Symptomatically, at times, Zuboff's narrative seems to lose sight of the systemic character of surveillance capitalism, equating it with the practices of individual firms like Google, Facebook, and Microsoft. Effectively, and in line with her functionalist leanings well-spotted by Morozov [Morozov, 2019], Zuboff does away with the structure vs. agency problem by casting it simply as a matter of scale, thus reducing economic imperatives to scalable business strategies, possibly even chosen at will. Yet the question remains, why did the strategy of capturing data exhaust become scalable in the first place? This is significant because Zuboff assumes that, at the bottom, capitalism is just a spontaneous response to the human need to live an 'effective life'. In the second chapter, she writes: 'Capitalism evolves in response to the needs of people in a time and place' [Zuboff, 2019: 36]. Superficially, this sentence seems to be historicising capitalism. In fact, it does precisely the opposite. While showing that surveillance cap- 
italism is a rogue mutation of capitalism produced by a series of contingent historical events, she at the same time assumes that capitalism tout court is simply a way of satisfying the human needs, thus sparing it of contingency and historicity.

\section{...And What is Right with It?}

Notwithstanding the influences of modernisation theory, the book does resonate very powerfully with some other contemporary critiques of capitalism. For example, Zuboff's point that the products of surveillance capitalism 'are about predicting us, without actually caring what we do or what is done to us' [Zuboff, 2019: 71], sounds strikingly similar to the late anthropologist David Graeber's [2006] argument about the affinity between violence and commerce. Both are extremely simplified forms of interaction that enable communication between strangers but do not require any interpretative labour necessary to understand each other. Violence and market exchanges enable one to 'have relatively predictable effects on other's actions without understanding anything about them', but do not require one to 'know or figure out who they think they are, what they want, find objectionable, etc.', except the 'single thing they want to acquire: gold, or fish, or calicoes' [Graeber, 2006: 76-77]. Interpretative labour is basically an effort of imagination: understanding ultimately requires imagining oneself in someone else's place. In another well-known piece, Graeber [Graeber, 2012] argued that hierarchical relationships tend to distribute the load of 'interpretative labour' very unevenly, producing ignorance at the top because those in control of wealth and power do not have to understand anyone else and are unable to imagine what it is like to be toiling far below the commanding heights. Thus, along with Foucauldian power/knowledge, one could also speak of power/ignorance [ibid.: 111]. Hierarchies can be simultaneously hierarchies of knowledge and ignorance: 'seeing like a state' is not the same as 'seeing like a peasant'. In fact, the former may be the exact inversion of the latter.

There are a few points on which Zuboff's account of surveillance capitalism seems to converge with Graeber's ideas. Zuboff is worried about the unequal distribution of knowledge that is getting concentrated in the hands of surveillance capitalists who use it to predict human behaviours, but what kind of knowledge is this? Does it make the algorithms - or the capitalists who own them — really so 'smart' as they claim? From the perspective outlined by Graeber, algorithms are paradoxical in the sense of being extremely knowledgeable and yet also extremely ignorant at the same time. Machine intelligence amasses so much data that no human being could ever possess, let alone process, but it is hardly capable of performing interpretative labour, even though it may pass the Turing test. The Big Other may be able to predict typical behaviours, but this does not necessarily amount to actual understanding, let alone anticipating what is genuinely new. In this sense, being smart as an algorithm may be practically equivalent to being stupid as a human being: just think about the annoying ads that are being shown to you in a completely inappropriate context, thus being experienced as a tactless intrusion, rather than smooth anticipation of what you really want, here and now.

This reading also sheds light on another issue in Zuboff's analysis - namely, her conspicuous silence on labour. Labour only gets mentioned in the context of its social division or as a fictitious commodity characteristic of the previous phase of capitalist 
development, since under surveillance capitalism, its place is taken by human experience. In other words, Zuboff does not treat labour as a counterpart to capital, and for a reason. Ultimately, her problem with surveillance capitalism is that it is not capitalist enough, at least in its relationships with the users who do not enjoy the reciprocities of workers in the mass-production era. They are just sources of raw materials and not a party in a supposedly reciprocal market exchange. But does this mean that labour - in the double sense of work and the working class - has no relevance in surveillance capitalism?

In his review of Zuboff, Morozov [Morozov, 2019] makes a similar point, noting that Google's advertising revenues depend on the work of engineers and computer scientists but also, crucially, on indexing content from other sites that is necessary to link search queries to targeted ads. Indexing production costs are negligible, 'as the indexed content arrives almost for free', performed by 'the usual suspects: bots, hobbyists, academics, teenagers. But also plenty of precarious media professionals' [ibidem]. Thus, surveillance capitalism may have its proletariat, after all. Just think about the numberless crowd of SEO professionals and copywriters who spend much of their working time doing 'interpretative labour', so that a search algorithm will be able to recognise and index some ad published by some online retailer. It is tempting to say that machine learning algorithms indeed are capital, not exactly in the sense implied by Zuboff, but more in line with the Marxian concept of fixed capital, a chunk of congealed dead labour - in this case, 'interpretative labour'. Perhaps the analysis should look beyond surveillance and include the ways in which 'interpretative labour' gets objectified in the form of algorithms and the 'living' labour of the workers who make these algorithms 'smart'? Perhaps, then, unlike the students of business who begin from the firm level, one should follow Marx and start from the elementary cell of surveillance capitalism - namely, its 'prediction products' - and then try to trace their origins to human 'interpretative labour' that gives them their certainty and, thereby, their value? Even if somewhat far-fetched, this direction of analysis seems promising, testifying to the book's richness and provocative character. Shoshana Zuboff's Surveillance Capitalism is a wonderful intellectual provocation, a must-read for anyone interested in contemporary mutations of capitalism and information technology, and a timely reminder that something may be rotten in the digital kingdom.

\section{References (Список литературы)}

Abbott A. (1993) The Sociology of Work and Occupations. Annual Review of Sociology. Vol. 19. P. 187-209. https://doi.org/10.1146/annurev.so.19.080193.001155.

Arendt H. (2004) The Origins of Totalitarianism. New York, NY: Schocken Books.

Beck U., Bonss W., Lau C. (2003) The Theory of Reflexive Modernization: Problematic, Hypotheses and Research Programme. Theory, Culture \& Society. Vol. 20. No. 2. 1-33. https://doi.org/10.1177/0263276403020002001.

Foster J. B., McChesney R. W. (2014) Surveillance Capitalism: Monopoly-Finance Capital, the Military-Industrial Complex, and the Digital Age. Monthly Review. Vol. 66. No. 3. P. 1-31. https://doi.org/10.14452/MR-066-03-2014-07_1. 
Graeber D. (2006) Turning Modes of Production Inside Out: Or, Why Capitalism is a Transformation of Slavery. Critique of Anthropology. Vol. 26. No. 1.61-85. https:// doi.org/10.1177/0308275X06061484.

Graeber D. (2012) Dead Zones of the Imagination: On Violence, Bureaucracy, and Interpretive Labor. The 2006 Malinowski Memorial Lecture. HAU: Journal of Ethnographic Theory. Vol. 2. No. 2. 105-128. URL: http://eprints.Ise.ac.uk/53222/ (accessed: 18.02.2021).

Harvey D. (2003) The New Imperialism. Oxford: Oxford University Press.

Hirschman A. O. (1970) Exit, Voice, and Loyalty: Responses to Decline in Firms, Organizations, and States. Cambridge, Mass: Harvard University Press.

Morozov E. (2019) Capitalism's New Cloth. The Baffler. February 4. URL: https://thebaffler.com/latest/capitalisms-new-clothes-morozov (accessed: 18.02.2021).

Polanyi K. (1957) The Great Transformation. Boston: Beacon Press.

Skinner B. F. (1976) About Behaviourism. New York, NY: Vintage Books.

Srnicek N. (2016) Platform Capitalism. Oxford: Polity Press.

Wood E. M. (1994). From Opportunity to Imperative: The History of the Market. Monthly Review. Vol. 46. No. 3. 14-40. https://doi.org/10.14452/MR-046-03-1994-07_2.

Zuboff S. (2015) Big Other: Surveillance Capitalism and the Prospects of an Information Civilization. Journal of Information Technology. Vol. 30. No. 1. P. 75-89. https:// doi.org/10.1057/jit.2015.5.

Zuboff S. (2019) The Age of Surveillance Capitalism: The Fight for the Human Future at the New Frontier of Power. New York: PublicAffairs. 